\title{
Total Glutathione and Glutathione Reductase in Bovine Erythrocytes and Liver Biopsy
}

\author{
Mahmoud Rushdi ABD ELLAH ${ }^{1,3)}$, Keiji OKADA ${ }^{1,4)}$, Masanobu GORYO ${ }^{2,4)}$, Saori KOBAYASHI ${ }^{4}$, Akihiro OISHI ${ }^{1,4)}$ and \\ Jun YASUDA ${ }^{1,4) *}$ \\ ${ }^{1)}$ Veterinary Teaching Hospital, Faculty of Agriculture, Iwate University, 3-18-8 Ueda, Morioka 020-8550, ${ }^{2)}$ Department of Disease \\ Control and Environmental Science, Faculty of Agriculture, Iwate University 3-18-8 Ueda, Morioka 020-8550, Japan, ${ }^{3)}$ Department of \\ Animal Medicine, Faculty of Veterinary Medicine, Assiut University, Assiut 71526, Egypt and ${ }^{4)}$ Department of Clinical Veterinary \\ Science, The United Graduate School of Veterinary Medicine, Gifu University, 1-1 Yanagido, Gifu 501-1193, Japan
}

(Received 1 September 2007/Accepted 25 April 2008)

ABSTRACT. The goal of the present study was to measure the total glutathione level and glutathione reductase activity in bovine erythrocytes and liver biopsy. Five cows were injected intraperitoneally with DL-ethionine $(12.5 \mathrm{mg} / \mathrm{kg} \mathrm{B}$.W.), and two control cows were injected with normal saline $(0.9 \% \mathrm{NaCl})$. Ultrasonography guided liver biopsy, and blood samples were collected at $0,4,7$ and 10 days after injection. The hepatic total glutathione level was significantly increased on Days $7(p<0.05)$ and $10(p<0.01)$, and hepatic glutathione reductase activity was significantly increased on Days $4(p<0.05), 7(p<0.01)$ and $10(p<0.01)$. There were insignificant changes in the erythrocytic total glutathione level. The present study demonstrated that liver biopsy is a valuable tool for detecting oxidative stress and for diagnosing hepatic dysfunction in cattle from the viewpoint of the status of glutathione and glutathione reductase. KEY WORDS: bovine liver biopsy, glutathione, glutathione reductase.

J. Vet. Med. Sci. 70(8): 861-864, 2008

Oxidative stress is a process based upon the action of free radicals formed by oxygen or other molecules and fragments. Free radicals are highly reactive substances produced continuously during metabolic processes and participate to a great extent in physiological events such as immune response, metabolism of unsaturated fatty acids and inflammatory reaction. However, their excess results in the impairment of DNA, enzymes and membranes [22]. Oxidative stress results when reactive forms of oxygen are produced faster than they can be safely neutralized by antioxidant mechanisms. The most important sources of free radical stress in the liver are hepatic disease, inflammation or exposure of the liver to a toxic agent [4].

Glutathione occurs mainly intracellularly primarily in the reduced form. Reduced glutathione fulfills several essential functions such as detoxification of oxygen-derived free radicals and storage and transfer of cysteine [12]. Cellular glutathione and related enzymes such as glutathione peroxidase, glutathione S-transferase and glutathione reductase are among the principal protective mechanisms against endogenous and exogenous toxic substances and free radicals-mediated damage in liver tissue as well as in other tissues $[5,8,9,13,14]$. Increased oxidative stress in bovine liver diseases was established in fatty liver [3] and liver abscesses [2]. In addition, underfeeding in cattle was reported to induce changes in the antioxidant systems in the liver [16]. The liver glutathione level in hepatic dysfunction induced by ethionine was extensively studied in rats $[10,19$, $24,25]$. It was reported that erythrocytic oxidative stress increased in human patients with severe hepatic disease $[17$,

\footnotetext{
* Correspondence to: Yasuda, J., Veterinary Teaching Hospital, Faculty of Agriculture, Iwate University, Japan.

e-mail: jyasuda@iwate-u.ac.jp
}

26]. In the current study, the erythrocytic glutathione level was measured to study the effect of hepatic dysfunction induced by ethionine on the erythrocytic oxidative status. The goal of the present study is to measure the total glutathione level and glutathione reductase activity in bovine erythrocytes and liver biopsy as indicators for increased oxidative stress and also to evaluate the effect of hepatic dysfunction on antioxidant levels in the liver and blood and their value in diagnosis from the viewpoint of the status of glutathione and glutathione reductase.

Seven Holstein cows (7-9 years old, 515 to $775 \mathrm{~kg}$ ) were used. No cows were pregnant, and none were lactating. Five cows were treated with DL-ethionine, and the remaining two cows were treated with normal saline $(0.9 \% \mathrm{NaCl})$ and kept as the control. Animal handling and procedures were conducted in strict accordance with the Animal Welfare Act and the Guide for the Care and Use of Laboratory Animals and approved by the Animal Experiment Committee in Iwate University, Japan. DL-ethionine (Kanto Chemical, Tokyo, Japan) dissolved in $0.9 \% \mathrm{NaCl}(20 \mathrm{mg} / \mathrm{m} l)$ was injected once intraperitoneally at a dose of $12.5 \mathrm{mg} / \mathrm{kg}$ body weight. Control cows were injected once intraperitoneally with $500 \mathrm{~m} l$ normal saline $(0.9 \% \mathrm{NaCl})$. Liver biopsy and whole blood samples were collected at $0,4,7$ and 10 days after ethionine injection. Liver biopsy for Day 0 was performed directly before DL-ethionine administration. On Day 0 , the biopsy site was selected on the right side of the cow in the 11th intercostal space, biopsy specimens for Days 4, 7 and 10 were selected in areas near the Day 0 specimen's site, and the biopsy areas were selected precisely with the aid of ultrasonography. Liver biopsy specimens were collected with the cows under procaine local anesthesia using a Bard ${ }^{\circledR}$ Magnum biopsy instrument and core $14 \mathrm{G}$ 
tissue biopsy needle (C.R. Bard, Covinton, GA, U.S.A.). Two liver biopsy specimens were used for the current experiment; one specimen was used to measure the hepatic total glutathione level and glutathione reductase activity, the other specimen was kept in neutral buffered formalin $10 \%$ for histopathological examination.

The liver biopsy specimen was washed twice in cold $0.9 \% \mathrm{NaCl}$, and then homogenized in 20 volumes (per weight tissues) of cold buffer (50 mM TRIS-HCL, pH 7.5) using a mechanical homogenizer surrounded by ice. After centrifugation of the homogenized samples at 5,000 $\times \mathrm{g}$ for $30 \mathrm{~min}$ at $4{ }^{\circ} \mathrm{C}$, the supernatant fluid containing the enzyme was removed and used to measure the hepatic total glutathione level ( $\mu \mathrm{mol} / \mathrm{g}$ protein), glutathione reductase activity (U/g protein) and total protein. Blood samples were collected in EDTA and then centrifuged at 3,500 rpm for 15 $\min$ at $4^{\circ} \mathrm{C}$. The plasma and buffy coat were drawn off directly after centrifugation, and the packed cells were washed twice with ten volumes of cold saline. The washed cells were hemolysed with 4 volumes of cold deionized water and used to measure the erythrocytes total glutathione level $(\mu \mathrm{mol} / \mathrm{g} \mathrm{Hb})$ and hemoglobin $(\mathrm{Hb})$ concentration. The hepatic and erythrocytic total glutathione level and hepatic glutathione reductase activity were measured using commercial test kits (OXIS International, Foster, CA, U.S.A.). Bioxytech $^{\circledR}$ GSH-420 assay was used for the total glutathione level, and Bioxytech ${ }^{\circledR}$ GR-340 assay was used for glutathione reductase activity. Assays were performed using a spectrophotometer (UV-1200 Spectrophotometer, Shimadzu, Kyoto, Japan). Total protein in the supernatant fluid of the liver homogenate was measured using an Autoanalyzer (Automatic Autoanalyzer 7060, Hitachi, Japan). $\mathrm{Hb}$ concentration of the hemolysate was measured using an automatic cell counter (Celltac alpha, MEK-6258, Nihon Kohden, Tokyo, Japan). Hepatic biopsies for histopathological examination were fixed in $10 \%$ neutral buffered formalin, sectioned, and then stained with hematoxylin and eosin (HE) and PAS stain [6]. Statistical analysis was performed by comparing data from Days 4, 7 and 10 with those from Day 0 using one-way ANOVA and Dunnett test

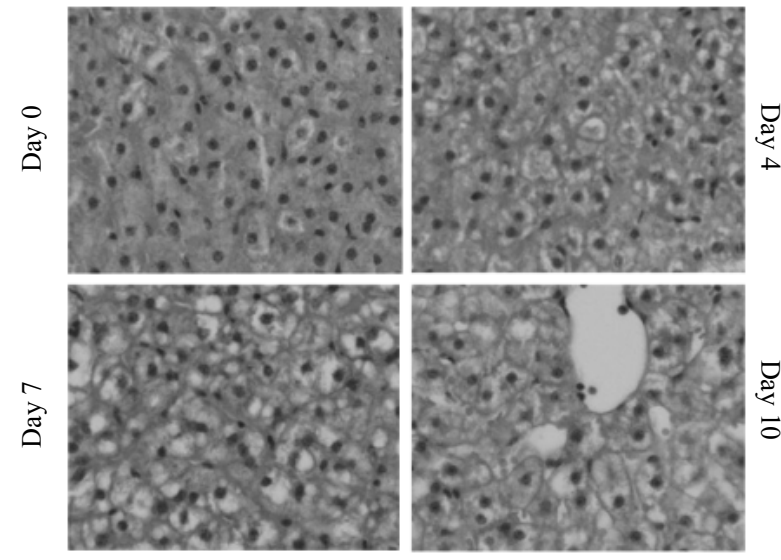

Fig. 1. Cattle liver in Days 0, 4, 7 and 10 before and after DL-ethionine administration showing glycogen degeneration and cell swelling, which varied from slight in days 4 and 10 to moderate in day 7 .

and was performed with Statistical Package for the Social Sciences for Windows (SPSS, version 10.0, Chicago, Ill, U.S.A.).

No apparent clinical signs were observed in animals during the experiment except that the weight of the animals decreased on Days 4, 7 and 10 compared with Day 0. Different degrees of cell swelling and glycogen degeneration were developed in the liver tissues, which varied in intensity from slight on Days 4 and 10 to moderate on Day 7 (Fig. 1). The hepatic total glutathione level ( $\mu \mathrm{mol} / \mathrm{g}$ protein) showed significant increase on Day $7(\mathrm{p}<0.05)$ and Day $10(\mathrm{p}<0.01)$, and hepatic glutathione reductase activity (U/g protein) showed significant increase on Days $4(p<0.05), 7(p<0.01)$ and $10(p<0.01)$. There was insignificant change in the erythrocytic total glutathione level $(\mu \mathrm{mol} / \mathrm{g} \mathrm{Hb})$ on Days 4 , 7 and 10 after DL-ethionine administration (Table 1).

Studies on the action of ethionine in cattle liver have shown that this ethyl analog of methionine produces a number of adverse effects including decrease in cholesterol ester, apolipoproteins A1, B-100 concentrations [15],

Table 1. Value of total glutathione and glutathione reductase in cattle erythrocytes and liver before and after DLethionine administration

\begin{tabular}{|c|c|c|c|c|c|}
\hline & Animals & Day 0 & Day 4 & Day 7 & Day 10 \\
\hline $\begin{array}{l}\text { Hepatic total } \\
\text { glutathione } \\
(\mu \mathrm{mol} / \mathrm{g} \text { protein })\end{array}$ & $\begin{array}{l}\text { Control }(\mathrm{n}=2) \\
\text { Ethionine group } \\
(\mathrm{n}=5)\end{array}$ & $\begin{array}{l}12.64 \\
11.67 \pm 1.79 \\
\end{array}$ & $\begin{array}{l}12.03 \\
12.54 \pm 1.18^{\mathrm{NS}}\end{array}$ & $15.84 \pm 3.30^{*}$ & $\begin{array}{l}9.05 \\
20.24 \pm 4.96^{* *}\end{array}$ \\
\hline $\begin{array}{l}\text { Hepatic glutathione } \\
\text { reductase } \\
\text { (U/g protein) }\end{array}$ & $\begin{array}{l}\text { Control }(\mathrm{n}=2) \\
\text { Ethionine group } \\
(\mathrm{n}=5)\end{array}$ & $\begin{array}{l}9.94 \\
8.20 \pm 1.71\end{array}$ & $\begin{array}{l}8.73 \\
11.55 \pm 2.13^{*}\end{array}$ & $\begin{array}{l}10.27 \\
20.24 \pm 5.23^{* *}\end{array}$ & $\begin{array}{l}8.86 \\
14.45 \pm 1.83^{* *}\end{array}$ \\
\hline $\begin{array}{l}\text { Erythrocytes total } \\
\text { glutathione } \\
(\mu \mathrm{mol} / \mathrm{g} \mathrm{Hb})\end{array}$ & $\begin{array}{l}\text { Control }(n=2) \\
\text { Ethionine group } \\
(n=5)\end{array}$ & $11.20 \pm 0.91$ & $\begin{array}{l}9.46 \\
10.95 \pm 1.68^{\mathrm{NS}}\end{array}$ & $\begin{array}{l}11.83 \\
11.25 \pm 1.99^{\mathrm{NS}}\end{array}$ & $\begin{array}{l}8.91 \\
11.14 \pm 1.30^{\mathrm{NS}}\end{array}$ \\
\hline
\end{tabular}

Data for control animals were presented as Mean value.

Data for ethionine treated group were presented as Mean \pm SD.

* Significant $\mathrm{p}<0.05, \quad * *$ Highly significant $\mathrm{p}<0.01$. 

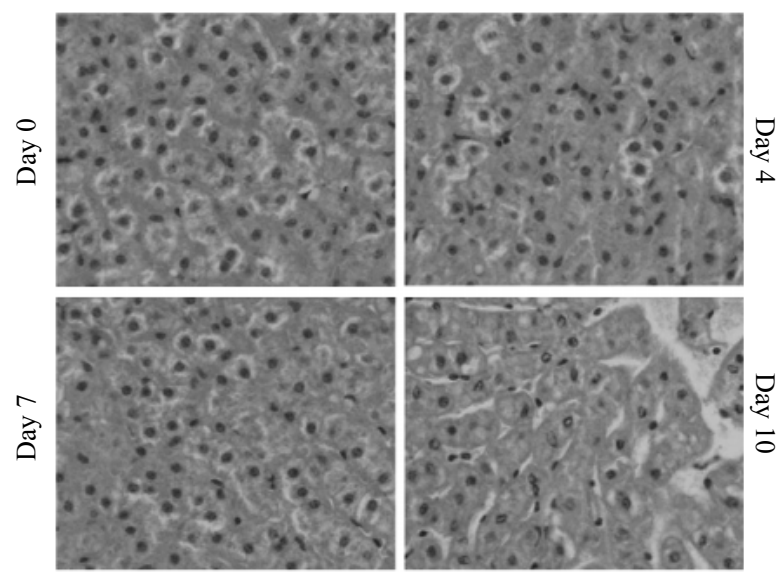

Fig. 2. Cattle liver from control animals in Days 0, 4, 7 and 10 before and after injection of normal saline $0.9 \%$.

reduced hepatic protein kinase $\mathrm{C}$ activity [11] and haptoglobin induction [20] and decreased serum lecithin:cholesterol acyltransferase activity [21]. Previous studies aimed to study different biochemical parameters in severe fatty degeneration in cattle, and hence DL-ethionine was injected at a dose of $25 \mathrm{mg} / \mathrm{kg} \mathrm{B.W.} \mathrm{[15,} \mathrm{20,} \mathrm{21].} \mathrm{However,} \mathrm{in} \mathrm{the}$ current study, DL-ethionine was administered at a dose of $12.5 \mathrm{mg} / \mathrm{kg} \mathrm{B.W}$., which is sufficient to produce hepatic dysfunction and not essentially fatty liver. According to the histopathological examination (Fig. 1), using ethionine at a dose of $12.5 \mathrm{mg} / \mathrm{kg} \mathrm{B.W}$. produced hepatic dysfunction in the form of glycogen degeneration and cell swelling, which varied in intensity from slight on Days 4 and 10 to moderate on Day 7 (Fig. 1). The sites of liver biopsy for the 4th, 7 th, and 10th day were selected precisely using ultrasonography near the site of the Day 0 biopsy to ensure that the biopsy samples were collected from the liver, and also to avoid the collection of multiple biopsy specimens from the same site, which may affect the measured parameters. The absence of hepatic histopathological changes in control cows (Fig. 2) indicated that the histopathological changes in the ethionine group were attributed to the toxic effect of ethionine on the liver.

In the present study, the changes in the hepatic total glutathione level and glutathione reductase activity may be attributed to a combination of hepatic dysfunction and the effect of ethionine. The absence of oxidative stress in natural cases of hepatic glycogen degeneration [3] indicated that the effect on hepatic antioxidant parameters in the current study may be attributed to ethionine. Ethionine was reported to affect the glutathione metabolism in rat liver a short period after injection, which varied from $4 \mathrm{hr}$ [25] to $24 \mathrm{hr}$ [10] followed by significant increase in 2 days [19] or 3 days [24]. Furthermore, the administration of ethionine induced an increase in the synthesis of the $\mathrm{H}_{2} \mathrm{O}_{2}$-generating peroxisomal beta-oxidation enzyme system in the rat liver. An imbalance between production and degradation due to high rates of the $\mathrm{H}_{2} \mathrm{O}_{2}$ generating peroxisomal beta-oxida- tion system can cause an intrahepatic oxidation stress [1]. $\mathrm{H}_{2} \mathrm{O}_{2}$ is a cytotoxic and can be converted to hydroxyl radical (.OH) via Fenton like reaction [18]. Catalase together with glutathione peroxidase (GSH-Px) plays an important role in the removal of $\mathrm{H}_{2} \mathrm{O}_{2}$ from the cell, where $\mathrm{H}_{2} \mathrm{O}_{2}$ is reduced to water [7]. Ethionine exposure was reported to inhibit hepatic catalase activity in rats [1], which activates the GSH-Px pathway to remove the excess $\mathrm{H}_{2} \mathrm{O}_{2}$. The endogenously produced $\mathrm{H}_{2} \mathrm{O}_{2}$ is reduced by reduced glutathione (GSH) in the presence of selenium dependent GSH-Px; as a consequence, GSH is oxidized to glutathione disulfide, which is rapidly reduced back to GSH by glutathione reductase in the presence of nicotinamide adenine dinucleotide phosphate (NADPH) [23]. This may explain the significant increase in the hepatic GSH level on Day 7 and Day 10 and in hepatic glutathione reductase activity on Days 4, 7 and 10 after ethionine injection. The insignificant changes in the erythrocytes total glutathione level (Table 1) indicate the absence of oxidative stress in the erythrocytes of cows suffering from glycogen degeneration and also indicate that DL- ethionine has no effect on the erythrocytes glutathione level when used at a dose of $12.5 \mathrm{mg} / \mathrm{kg} \mathrm{B}$.W., and the absence of oxidative stress in erythrocytes of cattle suffering from hepatic dysfunction was reported previously in natural cases of glycogen degeneration and fatty liver [2]. The present study demonstrated that liver biopsy is a valuable tool for detecting oxidative stress and for diagnosing hepatic dysfunction in cattle from the viewpoint of the status of glutathione and glutathione reductase. It is recommended to measure the glutathione level and glutathione reductase activity in liver biopsy from natural cases with glycogen degeneration to elucidate whether the increased oxidative stress was due to glycogen degeneration or due to the direct effect of ethionine on antioxidant parameters.

ACKNOWLEDGEMENTS. This work was supported by Grants-in-Aid for Basic Scientific Research (No. 17-05483) from the Ministry of Education, Culture, Sports, Science and Technology, Government of Japan and by the Japan Society for the Promotion of Science.

\section{REFERENCES}

1. Aarsaether, N., Aarsland, A., Kryvi, H., Nilsson, A., Svardal, A., Ueland, P. M. and Berge, R. K. 1989. Changes in peroxisomes and mitochondria in liver of ethionine exposed rats: a biochemical and morphological investigation. Carcinogenesis 10: 987-994.

2. Abd Ellah, M. R., Nishimori, K., Goryo, M., Okada, K. and Yasuda, J. 2002. Glucose 6 phosphate dehydrogenase and glutathione peroxidase activities in hepatic abscesses of cattle. Vet. Biochem. 39: 25-30.

3. Abd Ellah, M. R., Nishimori, K., Goryo, M., Okada, K. and Yasuda, J. 2004. Glutathione peroxidase and glucose 6-phosphate dehydrogenase activities in bovine blood and liver. $J$. Vet. Med. Sci. 66: 1219-1221.

4. Abd Ellah, M. R., Yasuda, J. and Okada, K. (2007): Oxidative stress and bovine liver diseases: Role of glutathione peroxidase and glucose 6-phosphate dehydrogenase. Review article. Jpn. 
J. Vet. Res. 54: 163-173.

5. Abou Ghalia, A. H. and Fouad, I. M. 2000. Glutathione and its metabolizing enzymes in patients with different benign and malignant diseases. Clin. Biochem. 8: 657-662.

6. Bancroft, J. D. and Stevens, A. 1982. p. 134. In: Theory and Practice of Histopathological Techniques, 2nd ed. Churchill Livingstone, Edinburgh.

7. DeLeve, L. D. and Kaplowitz, N. 1991. Glutathione metabolism and its role in hepatotoxicity. Pharmacol. Therapeutics 52: 287-305.

8. Gate, L., Paul, J., Nguyen, B. A., Tew, K. D. and Tapiero, H. 1999. Oxidative stress induced in pathologies: the role of antioxidants. Biomed. Pharmacother. 53: 169-180.

9. Hayes, J. D. and McLellan, L. I. 1999. Glutathione and glutathione-dependent enzymes represent a co-ordinately regulated defence against oxidative stress. Free Radic. Res. 31: 273-300.

10. Hsu, J. M., Buchanan, P. J., Anilane, J. and Anthony, W. L. 1968. Hepatic glutathione concentrations linked to ethionine toxicity in rats. Biochem. J. 106: 639.

11. Katoh, N. 1994. Reduced protein kinase C activity and endogenous protein phosphorylation in ethionine-induced fatty liver in cows. Vet. Res. Commun. 18: 423-432.

12. Krizanovic, D., Bozic, P., Vrbanac, B. G., Karadjole, I. and Petrusa, V. P. 1997. Glutathione and related enzyme activities in the blood of simmental bulls. Res. Vet. Sci. 63: 191-192.

13. Murphy, M. E., Scholich, H. and Sies, H. 1992. Protection by glutathione and other thiol compounds against the loss of protein thiols and tocopherol homologs during microsomal lipid peroxidation. Eur. J. Biochem. 210: 139-146.

14. Oberley, T. D. and Oberley, L. W. 1997. Antioxidant enzyme levels in cancer. Histol. Histopathol. 12: 525-535.

15. Oikawa, S. and Katoh, N. 1995. Enzyme linked immunosorbent assay for apolipoprote, in A-1 in the serum of cattle. Am. J. Vet. Res. 56: 409-414.

16. Sansinanea, A., Cerone, S., Virkel, G., Streitenberger, S., Gar- cia, M. and Auza, N. 2000. Nutritional condition affects the hepatic antioxidant systems in steers. Vet. Res. Commun. 24: 517-525.

17. Smith, J. R., Kay, N. E., Gottlieb, A. J. and Oski, F. A. 1975. Abnormal erythrocyte metabolism in hepatic disease. Blood 46: 955-964.

18. Stohs, S. J. and Bagchi, D. 1995. Oxidative stress in the toxicity of metal ions. Free Radic. Biol. Med. 18: 321-336.

19. Svardal, A. M., Ueland, P. M., Aarsaether, N., Aarsland, A. and Berge, R. K. 1988. Differential metabolic response of rat liver, kidney and spleen to ethionine exposure. S-adenosylamino acids, homocysteine and reduced glutathione in tissues. Carcinogenesis 9: 227-232.

20. Uchida, E., Katoh, N. and Takahashi, K. 1993. Induction of serum haptoglobin by administration of ethionine to cows. $J$. Vet. Med. Sci. 55: 501-502.

21. Uchida, E., Katoh, N. and Takahashi, K. 1995. The activity of lecithin:cholesterol acyltransferase in the serum of cows at parturition or with fatty liver. Vet. Res. Commun. 19: 343-351.

22. Vajdovich, P. 2001. Measurements of oxidative stress. Vet. Clin. Pathol. 30: 158.

23. Wang, W. and Ballatori, N. 1998. Endogenous glutathione conjugates: occurrence and biological functions. Pharmacological Rev. 50: 335-355.

24. Waterfield, C. J., Turton, J. A., Scales, M. D. C. and Timbrell, J. A. 1993. Investigations into the effects of various hepatotoxic compounds on urinary and liver taurine levels in rats. Arch. Toxicol. 67: 244-254

25. Waterfield, C. J., Westmoreland, C., Asker, D. S., Murdock, J. C., George, E. and Timbrell, J. A. 1998. Ethionine toxicity in vitro: the correlation of data from rat hepatocyte suspensions and monolayers with in vivo observations. Arch Toxicol. 72: 588-596.

26. Yasa, M. H., Kacmaz, M., Ozturk, H. S. and Durak, I. 1999. Antioxidant status of erythrocytes from patients with cirrhosis. Hepato-Gastroenterology 46: 2460-2463. 